\title{
LOCAL MOVEMENTS, POLITICAL PROCESSES AND TRANSFORMATION: A CASE STUDY OF BHAKTAPUR MUNICIPALITY
}

\author{
Suresh Dhakal * \\ Sanjeev Pokharel *
}

\section{Introduction}

"A small group of thoughtful committed citizens can change the world".

- M argaret Mead, Anthropologist

The people of $\mathrm{Nepal}$ have witnessed a number of political shifts within a comparatively short period of the country's history. The political revolution of 1950, which precedes all important political movements, eliminated the century-long Rana oligarchy and established the multiparty system. In 1960, late K ing M ahendra abolished the newly established multi-party system and implemented his own model of governance called the Panchayat system. The Panchayat system was designed to allow the King to rule the country according to his will, and the system alienated ordinary people from political processes. This system, too, came to an end after the popular movement of 1990 (widely known as jana andolan) which re-established the multi-party system in the country.

Every political transformation provided the $N$ epalese people with hopes about social progress and prosperity. However, no government established as the result of the political change could pay adequate attention to the inequalities inherent in Nepalese society. As a result, in spite of

* Suresh Dhakal holds M. A. in Anthropology from Tribhuvan U niversity and M. Phil from the U niversity of Bergen, N orway. He teaches Anthropology at the Central D epartment of Sociology/Anthropology. Currently, he is pursuing his Ph. D. research work in Anthropology from Tribhuvan U niversity.

** Sanjeev Pokhrel holds M. A. in Anthropology from Tribhuvan U niversity and M. Phil from the U niversity of Bergen, N orway. At present, he is a free-lance consultant. 
the changes in the system of governance, the problems faced by the $\mathrm{N}$ epalese people have remained unchanged. Even after the reestablishment of multi-party democracy in 1991, the traditional structures of poverty and deprivation continue to affect everyday lives of the majority of Nepalese. The low-caste groups, women, ethnic populations, etc. continue to suffer from the traditional systems of hierarchy, and were deliberately structurally excluded from the political processes, and thereby the economic and social opportunities it could provide (Lawoti, 2005). If democracy is to be considered an environment which allows people to participate in the process of social and economic transformation for achieving social progress and prosperity, it can be said that Nepalese people have not been able to experience democracy (Pandey, 1999). One of the possible reasons behind this problem could be the lack of participation of people in political processes. The political parties of $\mathrm{N}$ epal as well as the governments do not seem to be serious about involving people in political processes. As Dhakal (2004) argues, even after the re-establishment of democratic system, no political party has spent serious efforts in listening to the people about their desires, choices and priorities. The government's reliance on technocratic and bureaucratic knowledge in the process of social transformation have produced little, if not negative impacts, for the lives of poor and underprivileged $N$ epalese. As a result, majority of the population seems to be highly reluctant about the activities of both governments and political parties creating for them a serious crisis of legitimacy.

In spite of this critical situation, Bhaktapur M unicipality (BM), we argue, should be considered as one of the exceptional cases. The BM presents a unique case in which the local government functions as the machinery giving spaces for the local people to actively participate in the process of social and economic transformation (cf. Hachhethu 2004, Baral et. al. 2004, Grieve 2002). In other words, the people of BM have established social institutions through which they discuss on and prioritise their choices, expectations, and knowledge as parts of their social planning. The story of the construction of such institutions is both interesting and significant.

This study attempts to explain a story of partnerships, communities, political leadership, and management practices to show how with a 
political will good governance is possible even in a polity that is undergoing significant governability crises and an erosion of political institutions. By studying the transformation of the traditional city of Bhaktapur, we seek to complicate and problematise the discourse on democracy so that we can look beyond the subtle rhetoric of democracy and draw different conclusions.

By focusing on the relationship between political processes and the management of fohor (dirt/waste/garbage), we seek to understand the role of the local government in the social, cultural and economic transformation of Bhaktapur and her inhabitants. Following Laporte's (1985) historic analysis of the history of management of waste ('shit') in Paris, we seek to analyse the social and cultural changes in Bhaktapur through changing discourses concerning the management of the city's waste. We hope that this analysis will lead us to understand how the grounds for people's participation in social transformation were formed in the history of Bhaktapur's political movements.

This study is based mainly on our own observations of the Bhaktapur city across time, and, an intensive fieldwork period during 2004 and 2005. We interviewed some key persons such as the political leaders including the Chairperson of the Nepal Workers and Peasants Party (NWPP); some prominent scholars from Bhaktapur; and some local residents of different ages and backgrounds. In addition to this, we have also utilized a range of relevant literatures.

\section{Bhaktapur: An Image under Transformation}

In spite of being situated hardly 13 kilometres far from the main hubbub of the capital city, the image of Bhaktapur persists in the minds of most $\mathrm{N}$ epalese as a traditional $\mathrm{Newar}$ city lying in the far corner of the $K$ athmandu V alley. Old pantheons and monuments situated in the narrow streets and exotic jatras (celebration of festivity after the worship of local gods and goddesses) predominantly constitute the prima facie image of Bhaktapur. For example, the people of Kathmandu tend to believe that the people of Bhaktapur live their traditional lives in isolation (Grieve, 2002) having little interaction with the rest of the world. For them, Bhaktapur holds no capacity to stand the pace of recent changes which are taking place in Kathmandu and other big cities of $\mathrm{N}$ epal. 
Scholarly studies on Bhaktapur also tend to glorify Bhaktapur as a 'bounded' and 'unchanging' territory. For instance, anthropological studies on Bhaktapur describe and analyze either the rigid caste-based hierarchy or the exotic cultural practices. The ethnographies of Bhaktapur often tend to describe it as an integrated, homogenous, and territorially bounded community (Levy, 1990). Bhaktapur, as some of these studies seem to suggest, is conditioned by pre-industrial forms of production (Gutschow and Kölver 1975 quoted in Hachhethu 2004). In addition to this, anthropological studies on Bhaktapur show a tendency to deal with the downtrodden such as sweepers, farmers, craftsmen, potters, musicians, and so on (Parish, 1997). Thus, Bhaktapur exists in many scholarly books and articles as an isolated community in which people are comfortable more with traditional culture than with changes ( $\mathrm{H}$ al aand, 1982). N ot to surprise, the view that Bhaktapur is not 'modern' compared with the nearby cities such as Kathmandu and Patan is held by the locals of Bhaktapur themselves.

The academic discourses which describe the people of Bhaktapur as 'yet to be modern' category may be understood as the necessity of the discipline (M arcus and Fischer, 1986). However, Bhaktapur is not a 'living museum' as the brochure published by Nepal Tourism Board mentions. Significant progress achieved by Bhaktapur in areas such as education; health and hygiene; trade and commerce; and the development of infrastructure (such as roads, telecommunication, electricity, etc) contradict such description. A native political scientist Dr. Krishna $\mathrm{H}$ achhethu, for instance, disagrees with the view that Bhaktapur is a timeless and unchanging city (Hachhethu 2004). Grieve's (2002) study of the recent changes in Bhaktapur suggests that the romantic image of Bhaktapur as a traditional city seems misleading when we observe significant changes in the economic and social relationships of the local people. In our first field visit to the downtown Bhaktapur, we asked L alkaji Hada, a local bookseller, about what had actually changed in his place over the years. He replied, 'Bhaktapur is no longer fohor now. I think this is the biggest change'.

\section{Fohor and the Politics of Identity}

"D uring the end of my first year's study, I was thinking over the possible 
topics for my project work. Still in dilemma, I met Dr. Bimala Shrestha who is from Kathmandu to discuss on my project work. Upon hearing that I was from Bhaktapur, Dr Shrestha promptly said, 'Why don't you write something on the effects of dirty and filthy surroundings on the health of people? Y ou can do your field study in your own city as the people there have been affected by their dirty environment.' I felt very bad to hear her impression about Bhaktapur. I told her that Bhaktapur is now cleaner than any other city of Nepal".

-Ramila Silpakar, who stood first among girls in the SLC Examination Board held in 2002, talking with us about her recent experience at Bharatpur Medical College.

The remark of the bookseller may be a bit exaggeration. The doctor' $s$ remark, on the other hand, may have been based on the traditional and biased opinion about Bhaktapur and her people. However, their remarks suggest that fohor (dirt) is the most significant of all images associated with the identity of Bhaktapur and her people.

The people from other parts of the country commonly hold that the people of Bhaktapur look dirty and have no knowledge about how to manage their waste. Therefore, according to the general perception, the people of Bhaktapur dispose their private wastes such as faeces, garbage, animal blood, etc. on the public places such as streets, squares, meeting places, etc. The image of Bhaktapur as a 'dirty' or 'filthy' city, we argue, forms the basis for describing the city and her people as 'unchanging' and 'isolated'.

However, today's Bhaktapur does not fit within the conventional image of a fohor sahar. These days Bhaktapur has a well-functioning system of garbage collection and waste management which seem to have been successful in transforming the meaning of dirt/garbage from public burden to private responsibility. Although few ethnographic studies have focused on Bhaktapur's transformation in terms of its uniquely developed institutions of waste management, a simple observation of Bhaktapur's 'new face' suggests that such institutions are extraordinarily strong.

The new reputation of being a safa sahar (clean city) has a significant place in the new identity of Bhaktapur. People who have recently visited 
the city or heard about its recent changes often describe it as the cleanest among all big cities of $\mathrm{N}$ epal. N ot only the outsiders, the inhabitants of Bhaktapur themselves describe the recent safai (cleanliness) of the city as their biggest achievement so far. We observed a deep interest among the people of Bhaktapur to distinguish their city from other cities almost invariably on the basis of its safai. A statement by Narayanman Bijukchhe, the supreme leader NWPP, well reflects this interest:

"We need to work more actively towards making Bhaktapur the first clean, transparent and free-from-corruption municipality of the country."

-Comrade Narayan Man Bijukchhe in his speech given on the occasion of the general assembly of his municipal level political workers.

In addition to constructing a new and elevated image, the transformation of Bhaktapur as a safa sahar has yet another most important function. The idea of safai and the activities involved in the process of cleaning the city have provided a means for the people of Bhaktapur to dissociate themselves from their past; to communicate with outsiders with a new capacity; and to create an image of their future.

The efficient management of waste and the mass mobilization towards cleanliness are deeply embedded in the political and economic processes of Bhaktapur. Therefore, a careful examination of the transformation of political and economic processes may lead us to understand the story of transformation of Bhaktapur from a fohor sahar into a safa sahar. This story, we assume, can reflect the role of political will in the good governance of Bhaktapur.

\section{Political Processes and Safai Abhiyan}

The process of problematising the waste and/or associating it with human health seems to have started in Bhaktapur out of the political interest of a few communist youths. In 1962 comrade Narayan Man Bijukchhe, who is now the chairperson of NWPP, was elected as the member in Bhaktapur M unicipality ${ }^{17}$ in the local level election conducted under the erstwhile Panchayat system. An ardent supporter of the communist system of governance, comrade Bijukchhe was a member of the $Y$ outh L eague, 
a youth wing of then Communist Party of $\mathrm{Nepal}$ (CPN), instrumental in popularizing the values of communism among the masses. Comrade Bijukchhe saw this victory in the local level election as his opportunity to make people 'aware of their real constraints and possibilities'. $M$ oreover, that was an opportunity to 'reach the people and to organise them.' Bijuckhhe and his fellow comrades were prompted to participate in the local level election by the noble idea of Lenin: 'serve the people by utilising the state functionaries of the reactionaries' (Com Bijukchhe in personal communication).

However, given the political environment of the Panchayat period, the task was difficult and risky. The autocratic Panchayt system had banned all political parties and their activities. The government was not tolerant of any political campaigns in which people directly or indirectly debated on and/or criticized the Panchayat system, and anyone involved in such activities could be imprisoned or lose even her/his life. M oreover, the administration was well aware that comrade Bijukchhe was a communist activist in spite of being a member of the $P$ anchayati municipal council.

Therefore, in order to avoid unnecessary hassles from the central government, comrade Bijukchhe involved himself in the safai abhiyan (cleanliness campaigns) vis-à-vis development activities in his ward. These included the construction and renovation of roads, sewers, and irrigation canals; educating children and elderly people; opening of health posts; and cleaning of the neighbourhood. The efforts of comrade Bijukchhe and other members of the $Y$ outh League were directed towards receiving strong support and participation from among the local people to such programs. To meet this objective, comrade Bijukchhe and the members of the $Y$ outh L eague also organised frequent meetings of the local people mostly during nights. The local people also show ed interest in participating in such programs and gathered to discuss the development activities undergoing in their community.

For comrade Bijukche and his staunch supporters, the regularly held meetings and working together for development works were significant in two important ways. Firstly, this was an opportunity to spread the communist ideology to the masses in a more comfortable and 
effective manner. The political issues and ideologies (Ferguson 1994) could now be communicated and discussed while people were collectively involved in public meetings to clean neighbourhoods, maintain sewers, etc. Secondly, the danger from the administration had now been reduced to the minimum. The local administration could not intervene in such meetings and activities as they had to be considered the 'people's participation in the local development'. Such policy of the communist party members seems to have developed a new kind of public sphere in Bhaktapur where people could analyse, discuss and debate the issues concerning various spheres of their lives.

A mong these issues, safai was considered the most prominent. The communist party workers developed and popularized the idea that Bhaktapur needs to be cleaned, and it needs to be cleaned by the efforts of Bhaktapurians themselves. In the political scenario of the time, this idea had great political relevance for the communist party workers. On the one hand, people's voluntary participation in safai of their own tol (neighbourhood) could be a message to all that the existing government was not responsive to people's needs. On the other hand, it was a powerful method of organising people towards constructing a distinct identity of Bhaktapur. Com. Bijukchhe argues that the construction of this new identity of Bhaktapur was possible mainly because of the changes in the livelihood of poor farmers after the land reform movement in 1960s and $70 \mathrm{~s}$.

\section{B humisudhar Andolan and Changes in People's L ivelihood Conditions}

The $L$ and Reform Movement (Bhumisudhar Andolan) needs to be considered as vehicle for the most significant economic transformation which has changed the whole system of social relationships of the people of Bhaktapur (Hachhethu, 2004). The Land Reform Act implemented by the erstwhile Panchayat government in 1964 had little consequence for the traditional pattern of land distribution in the country. Although the Act was said to be designed to empower the real cultivators by providing them with cultivating right (mohiyani hak) as well as the agricultural land, it fell short in achieving its objectives (M ishra 1987). In Bhaktapur, however, the effects of the Act were immensely positive for the livelihood conditions of the local people (Hachhethu, 2004). The 
political processes initiated by the communist party workers of Bhaktapur, we argue, have played crucial role in this regard.

Unlike other communist factions in the country who criticized the A ct it being 'Royal Land Reform', promulgated as a hoax 'to strengthen the autocratic regime', Com Bijukchhe and his group in Bhaktapur welcomed the Act and decided to utilise the opportunity in favour of marginal farmers, J yapus in particular. They participated in bhumisudhar andolan by persuading the local farmers demanding formal registration of the mohiyani hak (tenants' right) to the mohis (tenant farmers) who had been traditionally suffering from exploitation due to the absence of such rights.

The local people's increasing participation in safai abhiyan as well as local development activities had al ready constructed and developed a strong public sphere which could effectively be utilised for the process of social and economic transformation. In this scenario, the $L$ and Reform Act announced in 1964 provided the people of Bhaktapur with an opportunity to ameliorate their livelihood conditions. This opportunity was actualised, thanks to the leadership provided by the communist party members. A great number of J yapus (low-caste Newars most of whom are farmers $)^{18}$ most of whom were landless and often exploited by the local high-caste landowners obtained the cultivating right as well as land.

Some elderly J yapus still describe with great agility the peasants' movement after the declaration of the Land Reform Act in 1964. Their eventful stories include descriptions of how the peasants captured agricultural produces from the landowners with force; how they obliged the landowners to register the names of the tenants while measuring and formally registering the land; and how the peasants forced the landowners to provide them with the receipt of the share of crops received by the latter. These stories suggest that the social movement had had significant consequences for Bhaktapur's social and economic scenario. To borrow comrade Narayan $\mathrm{M}$ an Bijukchhe's expression (personal communication, 2004), the peasants' movement was unique in the history of Bhaktapur as it had great positive consequences for the economic status of the underprivileged J yapu community.

Hachhethu (2004) argues that, "The Land Reform Act 1964 was a 
benchmark in bringing a substantial improvement in the economic conditions of Bhktapurians, the J yapus in particular. " He further observes, "Since 95 percent of farming households were tenants, the impact of the $L$ and Reform Act in improving the conditions of masses of Bhaktapur city is quite obvious" (Hachhethu, 2004). Krishna Bahadur (60), a local farmer from Jela tol of BM thus recalls his own experiences about the Bhumi Sudhar Andolan:

\section{Krishna Bahadur tells history!}

I can still remember that after the $L$ and Reform of mid-1960s, the local peasants started renovating the roof of their houses, frequently appeared in new clothes, and many started wearing shoes, enrolment in schools increased, new shops in the neighbourhood were being opened and so on. Likewise, farmers started buying improved seeds, chemical fertilisers, and harvested increased production. This eventually increased the purchasing capacity of the ordinary farmers. I think, if communists of Bhaktapur had not launched a peasants' movement at that time, we could not have come out of that harsh living conditions, instead would have continued the life of das (serfs) like earlier. I myself was a participant of the peasants' movements of that time. By 1968 AD, Jyapus of my neighbourhood started organising meetings at nights, which later resulted in a series of movements like Bharpai aandolan (asking for receipt of land tax from landowners), mohiyani hak (tenants rights), reduction of kut (land tax to be paid to landowners), saadhe dhapaune andolan (chase away the bulls) and so on. The results of all these movements were that we could acquire tenancy rights as provisioned by the $L$ and Reform Act, 1964. Earlier we were just halis, kind of 'bonded agricultural labour'. $L$ ater, we could retain the larger share of the production. F or example, previously we used to submit two third of paddy and half of wheat production to the landowner; in addition to that, farmers had to offer 'free but compulsory' labour to landowners. Later, we just started submitting 23 pathis per ropani, (i.e. approximately one-eighth of the total production in two crops), no other productions and no 'free but compulsory' labour to the landlords. If we wanted to discontinue tilling the landowners land, we could claim our share up to 50 percent of the land we had been tilling. My living condition which you see today would never have been possible if there was no Bhumi Sudhar. 
The success of the bhumi sudhar andolan in Bhaktapur was consequential not only for the social and economic lives of the local people but also for the political will of the communist party members who wanted to spread and strengthen their ideology among the masses, as elsewhere (Donham, 1999). It was mostly through this decade long andolan that the communist party members of Bhaktapur came into close affinity with the local people. As the andolan vis-à-vis the active participation of the communist party workers were seen positively by the Jyapu community who are a majority in Bhaktapur, the communist party members were successful in carving out their niche in the local politics and establishing themselves as the gurus of social transformation of B haktapur.

\section{Bhaktapur Development Project, Public T oilets and L ocal Perceptions}

Bhaktapur Development Project (BDP), locally known as the 'German Project' started in 1974 with the broad objectives such as 'improve the living standards of the local people' and 'preserve and renovate the historic city and its religious architecture' (Grieve, 2002: 285). The BDP worked in Bhaktapur for almost 20 years to fulfil those objectives. During that period, it renovated nearly two hundred ancient temples; and paved many kilometers of city road with bricks. Besides, the project helped in improving the lives of city dwellers, of J yapus in particular, by providing temporary jobs to many labour-based manual workers; and providing training for construction, the skills thus learned could be used for income generation in the future (Hachhethu, 2004). Some local people as well as the scholar studying Bhaktapur claim that the BDP's contribution in changing the physical appearance of the city and introducing social and economic changes of Bhaktapur was quite significant (cf. Hachhethu, 2004). Hence, BDP gained a wider recognition and popularity, outside the Bhaktapur in particular.

In addition to these developmental and conservationists programmes, the BDP had paid significant attention to the cleanliness of the Bhaktapur city. The fact that seventy percent of its development budget was allocated for conservation and cleanliness shows the concerns of BDP about the importance of safai in Bhaktapur. Even the individual households of inner city received NRs1, 500 under BDP project to build the private 
toilets. Besides, the BDP built sewers inside the city, and constructed more than twenty public toilets (Grieve, 2002).

For many of the people of Bhaktapur today, the success of BDP was a constructed reality, a 'myth'. M ost of the development activities of the BDP were marred with disbelief and resistance from the local people, and its activities directed towards safai are not exceptions. The comment that the BDP did not consult any local 'experts' while planning and implementing development activities and renovation programs is often put forward as an evidence to show that it was not participatory, people friendly, and, culturally oriented therefore not serious about preserving the history and tradition of Bhaktapur (Sagar Shrestha, BM Heritage Conservation Department). The BDP's decision to pave the roads with the bricks instead of stone slabs, for example, is considered to be an evidence of the thoughtless and 'stupid' work.

The local people's description of the toilets constructed by the BDP is even more interesting. Some local people told us that the public toilets constructed by the BDP were used by the pigs! As the local people would like to describe, the people of the B haktapur city were not interested in using them for two important reasons. First, the communist party of Bhaktapur did not want the local people use the infrastructure built by the 'reactionaries' of which BDP was considered a part. Secondly, the local people did not find it comfortable to go to the toilets 'along with others'.

Such analysis of the BDP's efforts to clean the city suggests that the management of fohor in Bhaktapur is not only a development agenda but also a way of expressing dissent. During our fieldwork, we were made aware about the fact that the people who did not like the local communist party, and for that matter the BM, used to throw their garbage to the streets through their windows. This makes it easier to understand why the local people did not like to use the public toilets constructed by the BDP. The public toilets constructed by the BDP were later demolished, and the local people were encouraged to make their private toilets inside their houses. 


\section{The Twenty Years That Changed the Image of Bhaktapur}

The transformed image of Bhaktapur, we argue, has a long historical process evolved along with the emergence and strengthening of communist politics led by NWPP. Now, we try to present the changes that took place in the last 20 years which eventually gave a transformed image to Bhaktapur. When we interviewed a number of local people in Bhaktapur about what are the major changes they have observed in the last twentyfive years: a generation, they categorically told us that changes have taken place in the spheres of politics, and consequently, in garbage management, health and sanitation, education and awareness, living condition, and so on.

A native scholar and a political scientist Dr. Hachhethu argues, "The modernization in social and economic spheres of Bhaktapur has a cumulative effect in bringing change to politics in the city. The 1982 local election, held under the partyless [P] anchayat regime, is a benchmark for transformation of the leadership of the BM into the J yapu community" (Hachethu, 2002).

\section{Transformation of Leadership: Shifting of Power Relations}

The NWPP continued its domination in BM for 20 years, a 'striking feature' (Baral 2004). Nonetheless, people have a common feeling that now they have their own people as representatives in the municipality and other local bodies. Prior to N W PP's participation in the local election under partlyless Panchyat system, such authorities used to be high-caste $\mathrm{N}$ ewars and non-N ewars. Those who introduced the communist politics in Bhaktapur some half century ago also belonged to the upper-caste $\mathrm{N}$ ewars. Hence, domination of upper-caste $\mathrm{N}$ ewars continued until the local election of 1982. A sudden and apparent shift in the leadership from the upper-castes to the local J yapus, the peasants which was apparently a non-political entity was a break-through in Bhaktapurian politics.

After the popular movement of 1990 and the restoration of democracy, the participation and representation of $J$ yapus in Bhaktapur $M$ unicipality increased significantly. The underlying reasons of this can be found in the political processes of Bhaktapur in which NWPP was 
actively involved in protecting the rights of the poor and landless J yapus during the bhumisudhar andolan of 1960s and 70s. This had given a sharp increase in the participation of Jyapu farmers in the political activities of NWPP. Therefore, it is quite natural that when NWPP participated and achieved success in the local level election after 1982, most of its elected representatives belonged to the J yapu community. The J yapus comprised of 68.42 per cent of the total local level representatives of BM formed after the local level election of 1982, which continued to increase in subsequent local level elections to reach 78.94 per cent in the election of 1999, when candidates of NWPP won 15 out of 17 ward chairpersons; $M$ ayor and Deputy $M$ ayor of BM.

The change in the leadership have affected many spheres of social and economic life of the people of Bhaktapur most of which are highly appreciated by the local people. BM which has been represented mostly by the Jyapus for the last 20 years seems to have been successful in acting as the agent to bring about those positive changes. Such changes are well manifested in the lives of J yapus and overall development of the BM. The paragraphs to follow will highlight some of such changes which can be regarded as the result of political will of the leading political party and its distinct policy for the development of the BM. BM has championed in maintaining democratic practices in its everyday functioning. Transparency International has awarded BM with recognition of "Island of Integrity' for its decade long anti-corruption standing and transparency.

\section{Safa Bhaktapur}

However, the only area in which the local government has earned wide popularity is the safai. Clean Bhaktapur has been the agenda as well as outcome of efforts of BM. As there is a longstanding history of safai movement in Bhaktapur, the aim has been changed. If the safai movement was used in the past to organize people and disseminate the 'communist' ideology to the masses, the emphasis on safai is concerned today with public health and attracting more tourists. However, in both of these cases, people's participation has remained a key issue. Safai now has turned out to be a measuring rod of the performance of municipality. 
To manage the dirt of the municipalility area, the BM has employed 196 staffs who are traditionally called 'sw eepers'. A mong these sweepers, 64 belong to the traditional sweeper castes known as podes, who are supposed to be the untouchables. The rest 132 belong to the Jyapu and non-J yapu Newars whose caste ranks are comparatively higher than the Podes.

For the Newars living outside Kathmandu, this might seem strange. The N ewars consider it a taboo for anyone except the Podes to be involved in the collection of garbage. The involvement of the Newars other than Podes in garbage collection in Bhaktapur is an outcome also of a political event of the past. A fter the NWPP swept virtually all the elected posts in the local level election of 1982, the traditional pode sweepers of the BM held a strike. These Podes who were supporters of other than NWPP had put forward their demands which were difficult to be fulfilled. To solve the immediate problem, the BM decided to replace the traditional Pode sweepers by the local non-pode Newars.

The new occupation of the non-Podes as the garbage collectors was, however, a strong move which could be considered a revolt against the traditional norms of the Newars. The non-Pode employes of the $B M$, therefore, had to bear heavy criticisms and sometimes social boycott because of their involvement in garbage collection. At this difficult juncture, the BM tried to portray garbage collection as the 'pure' task and also tried its best to dissociate garbage collection with the traditional caste status of the untouchable Podes. To fulfil this objective, the BM, drawing events associated with the lives of $M$ ao and $G$ andhi, encouraged and even glorified the task of garbage collection as a significant social service. The BM even published the photographs of the garbage collectors in its monthly magazine titled Bhaktapur vis-à-vis the pictures of great political leaders, writers, and other important personalities. Similarly, the BM made it an obligatory provision for the chairman of all wards and encouraged the high-caste people including Brahmins and reputed citizens such as doctors, engineers, etc. to sweep the roads occasionally. A ccording to BM statistics, now 72 percent of the households in the city has well managed toilet.

Transformation of Bhaktapur from fohar (dirty) to safa sahar (clean) 
is not only a prima-facie fact for an outsider but it also the most acclaimed fact for Bhaktapurians themselves. J anata Prasad Mitra, an old political activist, now runs a book stall near Durbar Square, remembers that previously, every year Bhaktapur town used to suffer from plague of cholera which used to claim several lives during the rainy summer seasons. Now the dwellers have got rid of that, just because the town has been clean now.

\section{E ducation and Safai}

In addition to safai, the BM has played equally crucial roles in the promotion of education among its inhabitants. Probably BM is the only municipality in the country which has undertaken different successful projects to enhance the educational capacity of its people. Comrade Bijukche justifies why his party, and consequently BM gave so much emphasis on education. He recalls the difficulties he faced when he had to organise people who were non-literate, and therefore, could not read the parties' documents and pamphlets. From this difficult experience, the communist party workers started a campaign of 'non-formal education' so that in Bijukchhe's words, the people are aware of what is happening within the country and in other parts of the world.

The BM 's success in the educational fields can be realised by the fact that the literacy rate of Bhaktapur city has more than doubled in every twenty years - 27 percent in 1971, 33 percent in 1981, 62 percent in 1991, and 74 percent in 2001 (CBS 2001), which supposedly rises by a few percent up to the date, is an outcome of 'mass educational awareness' (Hachhethu, 2004). This, for Comrade Bijukchhe, could not have been possible, if his party men had not oriented their efforts towards this direction. Non- Formal Education (NFE) campaign they initiated while the political parties and their political activities were still banned, during the Panchyat regime, or the efforts they made through a legal platform, i.e. municipality, after 1980 s, and more prominently after 1990 s in particular.

There can be many factors which have motivated the local communist party and the BM to work towards promoting education in Bhaktapur. However, the most important of such motivating factors seems to be 
safai. As the chairperson of NWPP, Com. Bijukchhe told us, " They felt that literacy and education was necessary for the people of Bhaktapur because without education they would not be able to understand the texts in the pamphlets of the BM and NWPP". Com Bijukchhe also feels that investment in education is directed to transforming Bhaktapur into an 'imagined city' as envisioned by him in his acclaimed work Saya Barsha Pachhiko Bhaktapur (Bhaktapur after 100 years).

\section{Tourism Tradition and Safai}

Tourism has remained an independent and perennial source of income of $\mathrm{BM}$ which is not controlled and regulated by the central government. Considering the economic benefit BM gets from tourism, BM has put all the possible efforts to attract tourists in Bhaktapur. The transformed image of Bhaktapur from a fohor sahar to safa sahar is both reason as well as outcome of 'tourism.'

For its architectural richness ${ }^{x i}$ Bhaktapur is known as the Rome of A sia. It has been one of the major attractions of tourists coming to $\mathrm{N}$ epal, for those who come for cultural tourism in particular; Bhaktapur has remained an unavoidable destination. For others, too, this cultural city a living heritage - has remained equal ly favourable destination. Bhaktapur, a monthly magazine published by BM quotes in every issue:

"Were here nothing else in $\mathrm{N}$ epal save the Darbar Square of Bhaktapur. It would be amply worth making a journey halfway round the globe to see. From the stand-point of the architect and the artist, Bhaktapur is a cave of Alladin. It is jumble of architectural fantasies, a vast store-house of the treasures of Newars art. In the Darbar Square al one are enough of carvings \& statues to fill up a score of great museum to overflowing." (E.A. Powel, 1929.The Last Home of M ystery. London. ).

Not surprisingly, tourism has been the biggest source of income for the BM. It introduced tourism service charge from 16 July 1996, which is $10 \$$ for non-SAARC tourists and NRs 50 for SAARC tourists now. In the year 2003/04 BM collected NRs. 1706250 from tourists from SAARC countries and NRs. 62984778 , that is total of NRs. 64691028 from a 
total of 119039 tourists and this is the highest share of BM's income source. For its outstanding efforts in preserving cultural heritage, BM has been awarded 'First Honourable Mention from A sia for 1998-99' by UNESCO; and has been recognised as 'Good Standing Member' by Organisation of World Heritage Cities (OWHC).

M ost importantly, the income from tourism is expended according to BM's overall goal of making a Bhaktapur an ideal city following NWPP's broader ideology and interest. BM's larger share of income comes from tourism but larger share of expenditure is allocated for safai and education.

The members of the BM have a vision of making B haktapur a cultural city - an ultimate tourist destination, for which the city has to be clean and all NWPP members have invariably acted in that direction. Unlike the local governments of other tourist centres of Nepal, the BM is successful in maintaining safai which is both the cause and effect of successful promotion of tourism industry in Bhaktapur. The overt and excessive interest of the BM in maintaining safai is, thus, directly related with the tourism industry which is again directly related to the health and well-being of the people. The difference between the tourism industry of other parts of the country and Bhaktapur's tourism industry lies in the fact that Bhaktapur has developed a concrete method of utilising its income for the welfare of the local people. Safai, we argue, should be considered one of such methods.

\section{Conclusions}

A program of social transformation - towards more modernity, towards more democracy - can achieve its desired goals if it takes into consideration the social, economic and cultural experiences of the people concerned. It is, therefore, important for a program of social transformation to be compatible with the constraints and opportunities faced by the people in their everyday lives (Ferguson, 1994). This is what motivates people to be both the agents and beneficiaries of social changes. Hence, 'grassroot participatory democracy' - builds on indigenous political traditions, based on the tradition of voluntarism and self-help, and a spirit that extols the committed and total involvement of all the members of a 
community in the formulation and implementation of policies for the community's welfare' (Paley,2002:474). Otherwise, "unless democracy becomes participatory in both nuance and substance it is always in peril" (Baral, 2004).

The case of B haktapur clearly illustrates this. D uring the Panchayat era, the communist party workers went among the people with the agenda to improve their conditions of living. Their participation in Safai Abhiyan and Bhumisudhar Andolan are prime examples in this connection. After 1990, when the same communist party members rose to power and formed the local government, they tried their best to give people what they needed most-such as safai, education, healthcare, employment and so on.

Ideologies hold no power in themselves to change a society. What is required is people's active involvement in the processes of determining not only the contents but also the course of social transformation. If people actively participate in the process of determining what needs to be changed and how, desired social changes are not difficult to obtain. In Nepal, few programs of social and economic transformation are based on people's own perception about how they can be made fruitful to them. The BDP's failure in winning co-operation from the local people can be interpreted as the result of its reluctance to involve the local people in its development and renovation programs. The BM, as we see it, is different in this regard. Even today, the BM implements a program after the concerned people adequately discuss and debate, and reach to the conclusion about how it should be designed and implemented in their respective areas.

The case of the unparalleled success achieved by the BM suggests that transparency and easy access to information are preconditions for the success of any program of social change. The BM is probably the only municipality of $\mathrm{Nepal}$ which is transparent about its every activity. It publishes not only its monthly incomes and expenditures but also the decisions made by the municipality board in its monthly magazine titled Bhaktapur. Similarly, the BM publishes in Bhaktapur every important issue which concerns the life of the city and its inhabitants. For example, when the plan for the renovation of Pachpanne J hyale Durbar (an old palace with fifty-five windows) was undergoing, the BM published the complete architectural design of the proposed building including its 
estimated cost. In our view, this custom has hel ped create a constructive a democratic public sphere where people openly think and discuss about how their local government is working and should work.

A nother crucial aspect of the functioning of the BM is its leadership pattern. As we see it, the leaders of the BM possess practical knowledge about social, economic and cultural conditions of the people with 'historical sensitivity' (D onham, 1990) and are committed to bring about positive changes in these conditions. The NWPP's traditional policy of involving the low-caste J yapus in the leadership of the municipality seems to have contributed to creating such a welcome environment. The high participation of J yapus in the leadership of BM (nearly 90 per cent of the BM's elected representatives belonged to the comparatively less privileged Jyapu community until the last local level election of 1997) has played important roles in promoting the participation of the real beneficiaries in the programs of Bhaktapur's social change and economic development. If Bolman and Deal (quoted in Baral 2004) are to be followed, leadership is an ability to pursue others to do what you want (power); to motivate people to get things done through persuasion; and vision. Leadership is, thus, facilitation which empowers people. In this regard, leaders of the BM and guiding party NWPP seem to have possessed all these qualities in them.

Thus, our study of the 'history, power and ideology' (Donham 1990) involved in the management of fohor in Bhaktapur suggests that freedom of expression, free elections, etc. are the means but not the ends of any democracy. A democratic environment can be established by strengthening the public spheres where people freely discuss and evaluate the conditions which affect their everyday lives. However, the success of democracy is judged by the people in terms of the substantive changes in their conditions of living. In the BM, we can see a unique scenario in which freedom of expression and free elections have been successfully utilised for the progress and prosperity of the municipality and its inhabitants. The most important preconditions for the success of a democracy, as we described above, are transparency of the government, participation of people, and commitment of the leaders. The BM, as we see it, to a large extent qualifies in all these regards. 
When people have the opportunity to discuss the problems and opportunities associated with their everyday lives among themselves, it is likely that they can also discover the measures to reduce the problems and utilise the opportunities.

One of the most important reasons behind the active participation of the people in BM seems to be the long political process initiated and strengthened by NWPP. As we described above, the NWPP's policy of involving local people in development works to organise resist against the erstwhile Panchayat system sowed the first seeds of people's participation in the process of social transformation.

Finally, if good politics and good governance are synonyms phrases: development is possible only through the good governance, and good governance is possible only through good politics. Good politics and good governance could rise up from participatory politics and sense of responsibility towards people and become transparent (www.ndf2004.gov.np). BM establishes a distinct example of this, despite the fact that there are still a lot more uneasy but 'right questions' are yet to be answered.

\section{Acknowledgements:}

Centre for the Studies of Developing Societies (CSDS), Delhi, commissioned this paper to us under its 'Democracy in South Asia' study project. We are indebted to LokNiti, CSDS, Delhi, and, NCCS, Kathmandu for entrusting this study to us. We are particularly thankful to Dr. Krishna Hachhethu, (NCCS), Edzia Carvalho and Peter Ronald deSouza (CSDS), Comrade Narayanman Bijukchhe, Chaityaraj Shakya, Ishwor Khowju, Ramila Shilpakar, Sagar Shrestha (Bhaktapur) for providing us valuable information and support. $M$ any people in Bhaktapur have shared their valuable ideas and opinions with us; we would like to thank them all. We are grateful to Dr. David Gellner, Oxford U niversity, who, upon our request, provided pertinent comments and suggestions. A $n$ abridged version of this paper was presented in the International Seminar in Kathmandu ('Social Sciences in a Multicultural World', December 11-13, 2006) organised by Sociological Anthropological Society of Nepal (SASON), we are thankful to all those who commented 
on our paper. We take sole responsibility for all shortcomings and remaining errors.

\section{Endnotes:}

i Bhaktapur is the smallest of 75 districts of the country in terms of geographical area. It is 119 square kilometers in size. There district has two municipalities (M adhyapur Thimi and Bhaktapur M unicipality) and 16 Village Development Committees. Total population of Bhkatapur according to 2001 census is 2, 25,561 where 51.29 are male and 48.71 female (CBS 2001). In terms of land use, out of 13846 ha, 80.21 percent of land is cultivable land, 14.06 percent forest area, and, 5.74 percent is settlement area. Bhaktapur M unicipality covers 6.88 square kilometers with a total population of 73,790 , i.e. 32.71 percent of the district population (CBS 2001).

ii According to available source, municipality in Bhktapur was established back in 1949. It was called as municipality from July 1949 to July 1950. Then it was called as Nagar Panchyat from July 1950 to M ay 1953, Nagarpalika from M ay 1953 to September 1962, again Nagar Panchyat from September 1962 to September 1988, then this was called as Nagar Panchyat Samiti till May 1990 which then was termed as Nagar Palika under the multiparty democracy. However, all those terms are almost synonymous for M unicipality.

iii M ore than 60 per cent of Bhaktapur's total population comprises of $J$ yapus (see Hathechhu 2004 p38). However, the term J aypus is not preferable term for Bhaktapurians, rather they use the term Kishan, the farmer. Gellner (1997) views in case of Bhaktaopur that 'communism can be an ideology which masks a kind of Jyapu ethnicity).

iv There are more than 172 temples, 36 ponds and kundas, 77 stone taps, 19 mathas (monasteries), 37 sattals, 152 wells, all with religious and social cultural values in Bhaktapur city.

\section{R eferences}

Baral, L.R., Hachhethu, K., Khanal, K.P., Kumar, D., Sharma, H. 2004 Nepal:Local Leadership \& Governance. New Delhi: Adroit Publishers.

Bhaktapur M uncipality Bhaktapur M onthly M agazine published by BM . V arious Issues.

Bijukche, N.M. 2059 BSSaya Barsha Pachiko Bhaktapur (Bhaktapur after a hundred years, in Nepali). Bhaktapur: Kendriay Prakashan Samiti, Nepal Majdur Kishan Party. 
Bista, D.B. 1990F atalism and D evelopment: Nepal's Struggle for M odernisation. Calcutta: Orient Longman.

CBS. 2001P opulation Census (National Report). Kathmandu: Central Bureau of Statistics.

Population of Nepal (Central Development Region). Kathmandu: Central Bureau of Statistics.

Population of Nepal (Village D evelopment Committees/M unicipalities) Kathmandu: Central Bureau of Statistics.

Dhakal, S. Sangroula, K. Bataman, G. 2004 Whose War? Economic and Sociocultural Impacts of Nepal's M aoist-G overnment C onflict. Kathmandu: NGO Federation Nepal.

Donham, D.L.1999 Marxist Modern: An Ethnographic history of Ethiopian Revolution Berkley: University of California Press.

1990History, Power, Ideology; Central Issues in Marxism and Anthropology. Cambridge: Cambridge University Press.

Ferguson, J. 1994TheAnti-PoliticsM achine: "D evelopment," Depoliticisation, and Bureaucratic Power in Lesotho. London: U niversity of M innesota Press.

Gellner, D.N. 1997'Caste, Communalism, and Communism: Newars and the Nepalese State', in David N. Gellner, Joanna Pfaff-Czarnecka, \& John Whelpton (eds.) Nationalism and Ethnicity in a Hindu Kingdom: The Politics of Culture in Contemporary Nepal. harwood A cademic publishers.

Grieve, G. 2002'Signs of Tradition: Compiling a History of development, Politics, and Tourism in Bhaktapur, N epal', Studies in Nepali History and Society, 7(2): $281-307$

Hachhethu, K. 2004'Social Change and Leadership Building: A Case Study of Bhaktapur C ity'. Paper presented in a W orkshop on The D ynamics of Social and Political Change in Nepal, organized by ILCAA, Tokyo, 28-29 February.

Haaland, A. 1982Bhaktapur: A Town Changing: Process Influenced by Bhaktapur Development Project. Bangkok: Craftsman Press.

Laporte, D. 1978 History of Shit. Cambridge: M IT

Lawoti, M. 2005Towards a Democratic NEPAL: Inclusive Political Institution for a Multicultural Society. Delhi: Sage Publication. 
Liechty. M. 2003Suitably Modern: Making Middle Class Culture in a New Consumer Society. Princeton: Princeton University Press.

Levy, R. 1990M esocosm: Hinduism and the Organisation of a Traditional Newar City in Nepal. Berkley: U niversity of California Press.

Mishra, C. 1987'Development and Underdevelopment: A Preliminary Sociological Perspective', Occasional Papers in Sociology and Anthropology. Kathmandu: Central Department of Sociology/A nthropology, TU. 1:105134.

Paley, J. 2002'Towards an Anthropology of Democracy'. Annual Review of Anthropology 2002 (31): 469-96.

Pandey, D.R. 1999Nepal's Failed Development: Reflections on the Mission and the Maladies.

Parish, S.M. 1997 Hierarchy and Discontent: Culture and Politics of consciousness in Caste Society. Delhi: Oxford University Press.

Scheibler, G. \& Scheibler-Shrestha, N. 2000 'On the Urbanity of Traditional N ewar City', in Ram Pratap Thapa \& J oachim Baaden (eds.) N epal: M yths and Realities. Delhi: Book Faith India.

Vaday, A. 1997 Events, Causes, and Explanation: Studies in Anthropology and Human E cology. New Y ork: Guilford Press. www.ndf2004.gov.np 